\title{
KINERJA KEPALA SEKOLAH MENENGAH ATAS BERBASIS ISLAM
}

\section{Jaja Jahari}

Darul Hikam Bandung Jl. Tubagus Ismail Depan No. 78 Bandung 40135

E-mail: jaja_jahari99@yahoo.co.id

\begin{abstract}
ABSTRAK
Penelitian ini bertujuan menemukan dan menganalisis faktor-faktor yang mempengaruhi kinerja kepala SMA berbasis Islam di Jawa Barat. Penelitian ini disebut dengan cross sectional research. Dalam menganalisis hubungan antar variabel digunakan pendekatan statistik uji analisis jalur (path analysis). Pengujian terdiri atas pengujian hipotesis secara simultan dan pengujian hipotesis secara individu dengan taraf kesalahan $\alpha=5 \%$. Sampel yang diteliti adalah 15\% dari jumlah populasi yaitu 57 sekolah dari 348 sekolah berbasis Islam yang ada di Provinsi jawa Barat. Hasil penelitian menunjukkan bahwa perilaku kepemimpinan, motivasi, kemampuan manajerial dan sistem kompensasi merupakan empat faktor yang secara langsung maupun tidak mempengaruhi kinerja kepala SMA berbasis Islam di Jawa Barat. Besarnya pengaruh masing-masing faktor yaitu; 1) kepemimpinan sebesar 25,6\%; 2) motivasi kerja sebesar 7,7\%;3) kemampuan manajerial sebesar 22,6\%; dan 4) sistem kompensasi sebesar $8,0 \%$. Urutan besarnya penilaian terhadap faktor-faktor tersebut yaitu 4,17 dengan tingkat kesesuaian 90,35\%; 4.01 dengan tingkat kesesuaian $83,34 \% ; 4,34$ dengan tingkat kesesuaian 92,18\%; 3.48 dengan tingkat kesesuaian sebesar $77,31 \%$.
\end{abstract}

Kata Kunci : Kinerja, Kepala Sekolah, SMA Berbasis Islam

\section{ABSTRACT}

This study aims to find and analyze the factors that affect the headmaster's performance of Islambased senior high schools in West Java. The study is a cross-sectional research. In this study, the relationship between variables was analyzed by using statistical approach (path analysis). The testing consisted of simultanious and individual bypothesis testing with error level $a=5 \%$. The sample was 57 schools it is the 15\% of the 348 Islam-based schools as the total population that exists in West Java Province. The results showed that leadership behavior, motivation, managerial skills and compensation system are the four factors that directly or indirectly affect the headmaster's performance of Islam-based senior high school in West Java. The degree of influence of each factor is as follows: 1) leadership was 25.6\%; 2) motivation to work was $7.7 \%$; 3) managerial capability was $22.6 \%$, and 4 ) the system of compensation was $8.0 \%$. Order of magnitude assessment of these factors is 4.17 with $90.35 \%$ degree of conformity; 4.01 with 83.34\% degree of conformity; 4.34 with $92.18 \%$ degree of conformity; 3.48 with degree of conformity of $77.31 \%$.

Keywords: Performance, Headmaster, Islam-based Senior High School 
Jaja Jahari

\section{PENDAHULUAN}

Dalam konteks pembangunan pendidikan jenjang SMA di Jawa Barat, khususnya pada SMA swasta berbasis Islam, terdapat kesenjangan antara tujuan pendidikan nasional dengan hasil pendidikan yang diperoleh. Indikatornya dapat dilihat dari berbagai kasus yang terjadi di kalangan pelajar dan dunia pendidikan bahwa pada generasi muda banyak terjadi pelanggaran nilai-nilai sosial, tawuran, penyalahgunaan obat-obat terlarang, pergaulan bebas, tidak disiplin, kurang empati dan berbahasa tidak santun (Sauri, 2006: 35). Kondisi tersebut menunjukkan bahwa antara tujuan pendidikan nasional dan kinerja sekolah sebagai pelaksana pendidikan formal bagi generasi bangsa masih belum harmoni.

Data hasil akreditasi Badan Akreditasi Nasional tahun 2009 pada jenjang SMA di Jawa Barat menunjukkan bahwa dari 318 SMA, 110 diantaranya adalah sekolah berbasis Islam. Dari 318 yang diakreditasi, 172 terakreditasi A, sisanya B dan C. Dari 172 (Sekolah Menengah Atas) SMA yang terakreditasi A, 39 diantaranya SMA berbasis Islam dan sisanya, 71 terakreditasi B dan C. Sebagai pembanding, sampai dengan tahun 2011, ada 1297 SMA yang terakreditasi yakni 829 akreditasi A, 404 akreditasi B dan 64 akreditasi C. Dari 829 SMA yang terakreditasi A, terdapat 408 SMA swasta terakreditasi A dan diantaranya 130 SMA berbasis Islam. Berarti sebagian besar sekolah yang berbasis Islam terakreditasi B yakni sebanyak 185 dan sisanya sebanyak 30 SMA terakreditasi C (http://www.ban-sm.or.id/provinsi/jawa-barat/akreditasi/view/). Berdasarkan capaian hasil penilaian akreditasi tersebut, diperoleh gambaran bahwa kinerja sekolah berbasis Islam di Jawa Barat secara kuantitatif belum menunjukkan hasil yang maksimal. Untuk itu perlu diteliti faktor-faktor yang mempengaruhi kinerja kepala SMA berbasis Islam khususnya di Jawa Barat diantaranya perilaku kepemimpinan, motivasi, kemampuan manajerial, sistem kompensasi yang dijalankan oleh yang bersangkutan.

Sampel yang digunakan dalam penelitian ini adalah 15\% dari jumlah populasi yaitu 57 sekolah dari 348 sekolah. Dari 57 sekolah tersebut, rata-rata responden diambil 3 orang, yaitu seorang kepala sekolah, guru dan karyawan. Dengan demikian seharusnya terkumpul 57 data kepala sekolah serta 114 data guru dan karyawan sehingga total menjadi 171 data. Akan tetapi, kenyataannya, data yang terkumpul justru berjumlah 176 data yang terdiri 53 tentang data Kepala sekolah dan 126 tentang data guru dan karyawan. Hal ini terjadi karena empat orang kepala sekolah tidak berhasil diperoleh datanya. Untuk menutupi kekurangan tersebut maka data tentang guru dan karyawan ditambah. Selanjutnya data tersebut diolah dan dianalisa sesuai dengan tujuan penelitian.

Instrumen penelitian untuk mengukur perilaku kepemimpinan terdiri atas 18 indikator, motivasi kerja sebanyak 15 indikator, kemampuan manajerial sebanyak 19 indikator, sistem kompensasi sebanyak 10 indikator dan kinerja kepala sekolah sebanyak 27 indikator. Dalam menganalisis hubungan antar variabel penelitian digunakan pendekatan statistik uji analisis jalur (path analysis). Pengujian terdiri atas pengujian hipotesis secara simultan dan pengujian hipotesis 
secara individu dengan taraf kesalahan $\alpha=5 \%$. Dengan demikian, jenis penelitian ini disebut cross sectional. Berikut adalah kerangka pemikiran dalam penelitian kinerja kepala sekolah pada sekolah yang berbasis Islam;

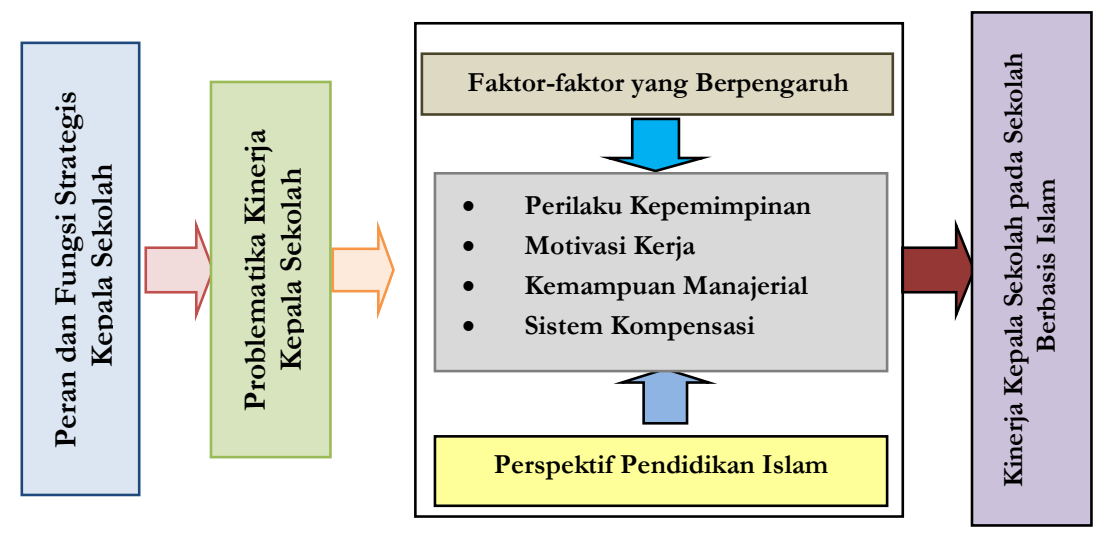

\section{PEMBAHASAN}

\section{Kepala Sekolah Dalam Perspektif Pendidikan Islam}

Fahmi (2011: 12) mengemukakan bahwa kinerja dapat dimaknai sebagai hasil yang diperoleh suatu organisasi baik organisasi tersebut bersifat profit oriented maupun non profit oriented yang dihasilkan selama satu periode waktu tertentu. Berarti kinerja merupakan hasil pekerjaan yang mempunyai hubungan kuat dengan tujuan strategis organisasi, kepuasaan konsumen dan memberikan kontribusi ekonomi. Dengan demikian kinerja adalah hasil kerja karyawan yang dilihat dari aspek seperti kualitas, kuantitas, waktu kerja dan kerja sama untuk mencapai tujuan yang sudah ditetapkan oleh organisasi. Secara umum terdapat empat aspek yang berhubungan dengan kinerja, yaitu; (1) kualitas yang dihasilkan, berkenaan dengan tingkat kesalahan, keefektifan penggunaan waktu dan ketepatan dalam melakukan tugas; (2) kuantitas yang dihasilkan, berkenaan dengan kuantitas/jumlah produk atau jasa yang dihasilkan; (3) waktu kerja, berkenaan dengan absensi, keterlambatan, serta masa kerja yang telah dijalani individu sebagai pegawai; (4) kerja sama, berkenaan dengan cara individu membantu atau menghambat usaha teman kerjanya. Dengan demikian kinerja pada dasarnya adalah produk waktu dan peluang. Hasil penilaian kinerja merupakan bagian penting dalam perencanaan strategis manajemen.

Berdasarkan penjelasan di atas, ada hubungan yang erat antara kinerja perorangan dengan lembaga atau organisasi. Dalam konteks pendidikan di lembaga persekolahan, kinerja dapat dimaknai sebagai hasil karya para pengelola sekolah berupa kualitas tata kelola, out put dan out come sekolah, yang merupakan hasil akumulasi dari proses kerja bersama antara kepala sekolah sebagai pemimpin dengan kolektivitas pendidik serta tenaga kependidikan yang ada di sekolah yang bersangkutan. Mulyasa (2011: 17) mengungkapkan bahwa 
kepemimpinan pendidikan berkaitan dengan masalah kepala sekolah dalam meningkatkan kesempatan untuk mengadakan pertemuan secara efektif dengan para guru dalam situasi yang kondusif. Dalam hal ini, perilaku kepala sekolah harus dapat mendorong kinerja para guru dengan menunjukkan rasa bersahabat, dekat dan penuh pertimbangan terhadap guru, baik sebagai individu maupun sebagai kelompok.

Faktor-faktor yang mempengaruhi kinerja individu tenaga kerja, menurut Robert L. Mathis dan John H. Jackson (2010: 156-157) adalah 1) kemampuan, 2) motivasi, 3) dukungan yang diterima, 4) keberadaan pekerjaan, dan 5) hubungan pekerja dengan organisasi. Ada dua variabel yang dapat mempengaruhi kinerja yaitu 1) Variabel individu yang terdiri atas pengalaman, pendidikan, jenis kelamin, umur, motivasi, keadaan fisik, kepribadian dan sikap; 2) Variabel situasional, yang terdiri atas dua faktor yaitu a) faktor sosial dari organisasi, serta b) faktor fisik dan pekerjaan. Penilaian kinerja (performance appraisal) pada dasarnya merupakan faktor kunci guna mengembangkan suatu organisasi secara efektif dan efisien. Penilaian kinerja adalah cara mengukur konstribusi individu (karyawan) kepada organisasi tempat mereka bekerja. Cascio (2005: 82) mengungkapkan bahwa penilaian kinerja adalah sebuah gambaran atau deskripsi yang sistematis tentang kekuatan dan kelemahan yang terkait dari seseorang atau sekelompok orang. Menurutnya, tujuan penilaian kinerja secara umum adalah untuk menghasilkan informasi yang akurat dan sahih berkenaan dengan perilaku dan kinerja anggota organisasi.

Kepemimpinan adalah kemampuan seseorang dalam menggerakan, mengarahkan, sekaligus mempengaruhi pola pikir, cara kerja setiap anggota agar bersikap mandiri dalam bekerja terutama dalam pengambilan keputusan untuk kepentingan percepatan pencapaian tujuan yang telah ditetapkan (Wahyudi, 2012: 120). C. A. Weber dalam Indrafachrudi (2006: 1) mengungkapkan bahwa "Leadership is the process by which people are induced to move forward toward some goal or purpose." Adapun fungsi pemimpin yang berhubungan dengan tujuan yang hendak dicapai menurut Indra Fachrudi (2006: 3) adalah memikirkan dan merumuskan dengan teliti tujuan kelompok, membantu anggota kelompok dalam mengumpulkan keterangan yang perlu supaya dapat mengadakan pertimbangan yang sehat, memberi dorongan kepada setiap anggota, memberi kepercayaan dan menyerahkan tanggung jawab kepada anggota. Menurutnya, dalam menjalankan misi kepemimpinannya, pemimpin memiliki fungsi utama sebagai (a) pengelola organisasi atau pengendalian utama manajemen berorganisasi; (b) motivator; (c) pembuat keputusan; (d) penilai terhadap kerja para anggota; (e) dinamisator dan katalisator organisasi; dan (f) supervisor.

Mulyasa (2011: 49-54) mengemukakan ada 11 ciri-ciri khusus kepala sekolah ideal yaitu: fokus pada kelompok, melimpahkan wewenang, merangsang kreativitas, memberi semangat dan motivasi, memikirkan program penyertaan bersama, kreatif dan proaktif, memperhatikan sumber daya manusia, membicarakan persaingan, membangun karakter, kepemimpinan yang tersebar 
dan bekerjasama dengan masyarakat. Sudarwan Danim (2009: 87-94) menambahkan bahwa pemimpin pendidikan, khususnya kepala sekolah, harus memenuhi kriteria berikut: mempercayai staf pengajar, mendelegasikan tugas dan wewenang, adiraga (fisik kuat), membagi dan memanfaatkan waktu, tampa toleransi atas ketidak-mampuan, peduli dengan staf pengajar, membangun visi, mengembangkan tujuan institusi, cekatan dan tegas sekaligus sabar, berani introspeksi, memiliki konsistensi, bersikap terbuka, serta berjati diri tinggi. Inilah profil manajer dan pemimpin pendidikan di era revolusi pengetahuan dan teknologi pada masa sekarang. Inovasi terus menerus akan menjadi jantung eksistensi yang senantiasa relevan dengan tantangan kekinian.

Menurut Antonio (2007: 198-204), Nabi Muhammad SAW merupakan sosok pemimpin pendidikan yang holistik karena beliau berakhlak mulia yakni memiliki karakteristik ikhlas, jujur, walk the talk, adil dan egaliter, tawâdlu', berani, berjiwa humor yang sehat, sabar dan menahan amarah, menjaga lisan, sinergi dan senantiasa bermusyawarah. Namun demikian, umumnya sosok kepemimpinan Nabi Muhammad SAW diidentikan dengan empat sifat saja yaitu shiddîq, amânah, tablìgh dan fathânah.

Kata shâdiq (orang yang jujur) berasal dari kata shidq (kejujuran). Kata shiddîq adalah bentuk penekanan (mubâlaghah) dari shadiq, yang artinya orang yang didominasi oleh kejujuran. Derajat terendah dari kejujuran adalah bila batin/hati seseorang selaras dengan perbuatan lahirnya (ucapan dan perbuatannya). Shiddîq adalah orang yang benar dalam kata-katanya sedang shiddî adalah orang yang benar-benar jujur dalam semua kata-kata, perbuatan dan keadaan batinnya. AlJunaid mengatakan bahwa inti kejujuran adalah berkata jujur di wilayah yang ketika seseorang berkata jujur, ia tidak akan selamat. Rasulullah SAW menegaskan bahwa sikap benar dan jujur akan membawa kepada kebaikan, surga, ketenangan, dan martabat syuhada. Hal ini difirmankan Allah SWT dalam surat An Nisa; 'Dan barang siapa yang menta'ati Allab dan Rasul-Nya, mereka itu akan bersama-sama dengan orang-orang yang dianugrabi nikmat oleh Allah, yaitu para nabi, orang-orang yang benar/jujur, orang-orangyang mati syabid dan orang-orang yang saleh. Dan meraka itulah teman yang sebaik-baiknya." (QS. An-Nisa [4]: 69). Ayat tersebut menunjukkan bahwa posisi orang-orang yang benar setara dengan mereka yang mati syahid. Berarti sifat shiddîq merupakan sifat yang amat penting untuk dimiliki oleh setiap orang, dan nabi telah menjadi teladan untuk sifat ini. Hal ini juga sejalan dengan hadis Nabi Muhammad SAW (Shahih Muslim: 222) dari Abdullah r.a. yang menyatakan; "Hendaklah kamu selalu berkata benar. Karena berlaku benar/jujur membimbing kepada kebajikan dan membawa ke surga. Seseorang yang senantiasa berlaku jujur dan berusaha mempertahankan kebenaran maka dicatat Allah sebagai shiddîq (orang yang jujur). Dan hindarilah olehmu dusta, karena sesunggubnya dusta itu membimbing kepada kejahatan dan kejahatan membawa ke neraka. Seseorang yang senantiasa berdusta dan mempertahankan kedustaan, maka dia dicatat oleb Allab SWT sebagai kadzâb (si pembohong)." 
Amânah yaitu segala sesuatu yang dipercayakan kepada manusia, baik yang menyangkut hak dirinya, hak orang lain, maupun hak Allah SWT; atau sesuatu yang diberikan kepada seseorang yang dinilai memiliki kemampuan untuk mengembannya. Ibnu Katsir (2003: 31) menjelaskan amanah ini sebagai kewajiban yang harus dilaksanakan. Ia menambahkan bahwa amanah adalah segala macam amal perbuatan yang diamanahkan Allah SWT kepada hambahamba-Nya. Maksudnya adalah kewajiban. Ahmad Mustafa Al Maraghi (1994: 363) menjelaskan bahwa amanah ini adalah tiap-tiap hak materi ataupun maknawi yang wajib ditunaikan kepada yang berhak menerimanya. Nabi dikatakan amanah karena beliau memiliki kualitas personal yang layak untuk dipercaya. Kualitas itu antara lain mencakup kualitas moral, kualitas keahlian atau profesional dan kualitas ril hasil persenyawaan antara kualitas moral dan keahilan/ profesional.

Tabligh dalam makna bahasa berarti menyampaikan sedangkan dalam makna istilah, tabligh adalah menyampaikan ajaran-ajaran Islam yang diterima dari Allah SWT kepada umat manusia untuk dijadikan pedoman dan dilaksanakan agar memperoleh kebahagiaan dunia dan akhirat. Isi yang utama dan pokok aktivitas tablîgh adalah amar ma'ruf nabi munkar. Tablîgh secara hakikat adalah hadirnya kekuatan seruan nurani yang senantiasa mengajak diri agar senantiasa tetap dalam keimanan, keislaman, keihsanan dan ketauhidan. Karakter tabligh ini tercermin dari perilaku Rasulullah karena beliau memiliki: kemampuan yang bagus dalam menyampaikan informasi, berita, wahyu, perintah, larangan, isi hati, ide, gagasan, kemampuan menentukan strategi komunikasi yang sesuai dengan sasarannya sehingga terhindar dari fitnah akibat kesalahpahaman; dan kemampuan dalam memilih bahasa yang jelas dan dapat dipahami oleh orang yang menerimanya (khâtibun n-nâsi bi qadri uqûlibim). Karakter tablîgh merupakan kunci dan erat kaitannya dengan membangun relasi, hubungan yang harmonis dan jalinan komunikasi baik antara sesama maupun antara atasan dan bawahan. Fathânah adalah hikmah yang diberikan Allah SW'T kepada siapa saja yang dikehendaki-Nya sebagai salah satu buah ketaatan dalam beribadah. Seseorang dengan memiliki sifat fathânah dapat bersikap bijaksana dan kuat dalam melakukan perubahan, perbaikan, pengembangan dan penyembuhan. Ia juga akan dapat paham dan eksis di dalam rahasia ketuhanan dan terhindar dari kebodohan ruhani. Menurut Al Banjari (2007: 47) indikasi seorang pemimpin yang memiliki sifat fathânab adalah buah pemikiran yang mudah dipahami dan diamalkan. Sifat fathânah Rasulullah SAW ditunjukan oleh kemampuannya dalam berpikir kreatif, inovatif dan positif (positive thinking).

Badan atau lembaga penyelenggara pendidikan, baik pemerintah maupun swasta (biasanya berbentuk yayasan) berfungsi sebagai motor penggerak utama sekaligus penanggung jawab penuh terselenggaranya pendidikan di sekolah yang dipimpinnya. Setiap lembaga penyelenggara pendidikan harus selalu mengupayakan agar setiap kegiatan atau aktivitasnya dilaksanakan dengan profesional dan penuh tanggung jawab. Dalam konteks kepemimpinan Islam, 
orang yang memimpin lembaga pendidikan (swasta maupun negeri) seyogyanya memiliki kriteria yakni di satu sisi kuat dalam aqidah, ibadah dan mu'amalah/berakhlak mulia (akblâq karimah) dan di sisi lain menguasai manajemen, yakni fokus kepada tugas/jabatan yang diemban, tidak semata-mata mencari keuntungan materi serta piawai menjalin hubungan yang baik dan harmonis baik secara internal maupun eksternal.

Wahjosumidjo (2011: 394-395) mengungkapkan bahwa kompetensi yang harus dimiliki kepala sekolah yaitu: (a) kemampuan menganalisis personal (problem analysis); (b) kemampuan memberikan pertimbangan, pendapat dan keputusan; (c) kemampuan mengatur sumber daya dan berbagai macam kegiatan; (d) kemampuan mengambil keputusan; (e) kemampuan memimpin; (f) memiliki kepekaan (sensitivity); (g) bersifat lapang dada dan sabar (stress tolerance); (h) kemampuan berkomunikasi secara lisan; (i) kemampuan berkomunikasi secara tertulis; (j) aktif berpartisipasi dan mendiskusikan berbagai macam subjek; dan (k) memiliki motivasi pribadi yang tinggi.

Daryanto (2011: 87-91) menyebutkan bahwa ada seperangkat kompetensi yang harus dimiliki oleh kepala sekolah sebagai pemimpin pembelajaran yaitu: (a) merumuskan dan mengartikulasikan tujuan pembelajaran; (b) mengarahkan dan membimbing pengembangan kurikulum; (d) membimbing pengembangan dan perbaikan proses belajar mengajar (PBM); (e) mengevaluasi kinerja guru dan mengembangkannya; (f) membangun komunikasi pembelajaran; (g) menerapkan kepemimpinan visioner dan situasional; (h) melayani siswa dengan prima; (i) melakukan perbaikan secara terus-menerus; (j) menerapkan karakteristik kepala sekolah efektif; (k) membangun warga sekolah agar pro-perubahan; (l) membangun team work yang kompak; dan (m) memberikan contoh dan menginspirasi warga sekolah.

Winardi (2011: 63) mengungkapkan, ada dua variabel yang paling penting dalam hubungannya dengan kinerja pekerja, yakni motivasi kerja dan kemampuan pekerja. Hubungan antar dua variabel tersebut adalah "Kinerja = Motivasi x Kemampuan”. Variabel yang mempengaruhi kinerja seseorang bukan hanya motivasi dan kemampuan. Penetapan tujuan-tujuan dapat memperbesar kemungkinan pencapaian kinerja baik (Miner, 1980: 168). Di antara karakter tujuan yang dapat mendorong kinerja seseorang/organisasi bertambah baik yaitu; Pertama, tujuan harus bersifat spesifik. Apabila situasinya memungkinkan, tujuan harus dikuantifikasi. Para manajer tidak perlu menekan para pekerja bidang produksi atau para tenaga penjual mereka untuk melakukan upaya maksimal dan menetapkan tujuan-tujuan spesifik yang dapat diupayakan pencapaiannya oleh para pekerja. Kedua, kinerja para pegawai akan lebih tinggi apabila tujuan-tujuan yang ditetapkan diterima oleh pihak yang harus melaksanakan pencapaiannya. Salah satu cara yang baik untuk meningkatkan "penerimaan tujuan-tujuan" oleh para pegawai adalah menyuruh mereka berpartisipasi dalam hal pengembangan tujuan-tujuan. Ketiga, tujuan-tujuan yang ditetapkan harus cukup sulit (pencapaiannya), sehingga para pekerja harus 
bekerja keras untuk mencapainya, tetapi tidak terlalu sulit hingga mereka cenderung akan "menyerah". Andaikata tujuan-tujuan terlampau mudah pencapaiannya, maka akan timbul perasaan apatis dan sikap kurang antusias dari para pekerja. Namun demikian apabila tujuan-tujuan terlampau sulit maka karyawan akan mempunyai persepsi bahwa sistem yang ada tidak fair. Akibatnya, motivasi pekerja akan sulit tumbuh dan berkembang. Dengan demikian, dapat dikatakan bahwa tujuan-tujuan yang tingkat kesulitannya berada dalam rentang menengah merupakan tujuan-tujuan yang paling efektif dalam merangsang para bawahan untuk bekerja dengan lebih baik (Winardi, 2001: 64-65).

Tugas seorang pemimpin dalam sebuah organisasi, termasuk organisasi pendidikan adalah menciptakan kondisi yang memungkinkan potensi motivasi dan kemampuan pada diri seseorang berkembang sehingga menjadi faktor pendukung meningkatnya kinerja seseorang dalam bekerja. Hasibuan (2010: 93) mengungkapkan, setidaknya ada empat alasan utama yang menyebabkan motivasi itu harus terus dilakukan oleh pimpinan terhadap bawahannya, yakni: 1) karena pimpinan mendistribusikan pekerjaan kepada para bawahan untuk dikerjakan dengan baik; 2) karena adanya bawahan yang mampu untuk mengerjakan pekerjaannya, tetapi ia malas atau kurang bergairah dalam mengerjakannya; 3) untuk memelihara dan atau meningkatkan kegairahan kerja bawahan dalam menyelesaikan tugas-tugasnya; 4) untuk memberikan penghargaan dan kepuasaan kerja kepada bawahannya. Winardi (2001: 114) membuat persamaan kinerja individual yang menjadi dasar hubungan antara kinerja dengan motivasi kerja yaitu;

$$
\text { KINERJA }=\begin{gathered}
\text { SIFAT-SIFAT } \\
\text { INDIVIDUAL }
\end{gathered} \quad \mathrm{x} \text { UPAYA KINERJA } \mathrm{x} \quad \begin{gathered}
\text { BANTUAN } \\
\text { KEORGANISASIAN }
\end{gathered}
$$

Persamaan di atas mengarahkan perhatian kepada sifat-sifat individual, upaya kerja dan bantuan keorganisasian sebagai tiga buah variabel yang saling mempengaruhi kinerja individual.

Pengetahuan, keterampilan dan nilai-nilai dasar yang direfleksikan kepala sekolah dalam menjalankan tugas sebagai administrator tidak dapat dilepaskan dengan kompetensi manajerial yakni conceptual skills, buman skills, and technical skills. Ada sejumlah kompetensi yang harus dimiliki oleh seorang kepala sekolah yaitu: (a) kemampuan menganalisis personal (problem analysis); (b) kemampuan memberikan pertimbangan, pendapat dan keputusan; (c) kemampuan mengatur sumber daya dan berbagai macam kegiatan; (d) kemampuan mengambil keputusan; (e) kemampuan memimpin; (f) memiliki kepekaan (sensitivity); (g) bersifat lapang dada dan sabar (stress tolerance); (h) kemampuan berkomunikasi secara lisan; (i) kemampuan berkomunikasi secara tertulis; (j) aktif berpartisipasi dan mendiskusikan berbagai macam subjek; (k) memiliki motivasi pribadi yang tinggi (Wahyudi, 2012: 35).

Kebijakan tentang kompetensi kepala sekolah tertulis dalam Peraturan Menteri Pendidikan Nasional Republik Indonesia Nomor 13 Tahun 2007 
tentang Standar Kepala Sekolah/Madrasah. Menurut Peraturan Menteri tersebut terdapat lima dimensi kompetensi yang harus dipenuhi oleh seorang kepala sekolah yakni kompetensi kepribadian, manajerial, kewirausahaan, supervisi dan sosial. Kompetensi dasar dari kelima standar kompetensi kepala sekolah tersebut dapat dilihat dalam tabel berikut:

\begin{tabular}{|c|c|c|c|}
\hline No & $\begin{array}{c}\text { Dimensi } \\
\text { Kompetensi }\end{array}$ & & Kompetensi \\
\hline \multirow[t]{6}{*}{1.} & \multirow[t]{6}{*}{ Kepribadian } & 1.1 & $\begin{array}{l}\text { Berakhlak mulia, mengembangkan budaya dan tradisi akhlak } \\
\text { mulia, dan menjadi teladan akhlak mulia bagi komunitas di } \\
\text { sekolah/madrasah. }\end{array}$ \\
\hline & & 1.2 & Memiliki Integritas kepribadian sebagai pemimpin. \\
\hline & & 1.3 & $\begin{array}{l}\text { Memiliki keinginan yang kuat dalam pengembangan diri } \\
\text { sebagai kepala sekolah/madrasah }\end{array}$ \\
\hline & & 1.4 & Bersikap terbuka dalam melaksanakan tugas pokok dan fungsi. \\
\hline & & 1.5 & $\begin{array}{l}\text { Mengendalikan diri dalam menghadapi masalah dalam } \\
\text { pekerjaan sebagai kepala sekolah/madrasah }\end{array}$ \\
\hline & & 1.6 & $\begin{array}{l}\text { Memiliki bakat dan minat jabatan sebagai pemimpin } \\
\text { pendidikan. }\end{array}$ \\
\hline \multirow[t]{13}{*}{2.} & \multirow[t]{13}{*}{ Manajerial } & & $\begin{array}{l}\text { Menyusun perencanaan sekolah/madrasah untuk berbagai } \\
\text { tingkatan perencanaan. }\end{array}$ \\
\hline & & 2.2 & $\begin{array}{l}\text { Mengembangkan organisasi sekolah/madrasah sesuai dengan } \\
\text { kebutuhan }\end{array}$ \\
\hline & & 2.3 & $\begin{array}{l}\text { Memimpin sekolah/madrasah dalam rangka pendayagunaan } \\
\text { sumber daya sekolah/madrasah secara optimal. }\end{array}$ \\
\hline & & 2.4 & $\begin{array}{l}\text { Mengelola perubahan dan pengembangan sekolah/madrasah } \\
\text { menuju organisasi pembelajaran yang efektif }\end{array}$ \\
\hline & & & $\begin{array}{l}\text { Menciptakan budaya dan iklim sekolah/madrasah yang } \\
\text { kondusif dan inovatif bagi pembelajaran peserta didik }\end{array}$ \\
\hline & & 2.6 & $\begin{array}{l}\text { Mengelola guru dan staf dalam rangka pendayagunaan sumber } \\
\text { daya manusia secara optimal. }\end{array}$ \\
\hline & & 2.7 & $\begin{array}{l}\text { Mengelola sarana dan prasarana sekolah/madrasah dalam } \\
\text { rangka pendayagunaan secara optimal. }\end{array}$ \\
\hline & & 2.8 & $\begin{array}{l}\text { Mengelola hubungan sekolah/madrasah dan masyarakat dalam } \\
\text { rangka pencarian dukungan ide, sumber belajar, dan } \\
\text { pembiayaan sekolah. }\end{array}$ \\
\hline & & 2.9 & $\begin{array}{l}\text { Mengelola peserta didik dalam rangka penerimaan peserta } \\
\text { didik baru, dan penempatan dan pengembangan kapasitas } \\
\text { peserta didik. }\end{array}$ \\
\hline & & & $\begin{array}{l}\text { Mengelola pengembangan } \\
\text { pembelajaran sesuai dengan arah dan tujuan pendidikan } \\
\text { nasional. }\end{array}$ \\
\hline & & 2.11 & $\begin{array}{l}\text { Mengelola keuangan sekolah/madrasah sesuai dengan prinsip } \\
\text { pengelolaan yang accountable, transparan dan efisien. }\end{array}$ \\
\hline & & 2.12 & $\begin{array}{lcc}\text { Mengelola ketatausahaan } & \text { sekolah/madrasah } & \text { dalam } \\
\text { mendukung pencapaian tujuan } & \text { sekolah/madrasah }\end{array}$ \\
\hline & & 2.13 & $\begin{array}{l}\text { Mengelola unit layanan khusus sekolah/madrasah dalam } \\
\text { mendukung kegiatan pembelajaran dan kegiatan peserta didik }\end{array}$ \\
\hline
\end{tabular}




\begin{tabular}{|c|c|c|}
\hline \multirow[t]{5}{*}{ No } & \multirow[t]{5}{*}{$\begin{array}{c}\text { Dimensi } \\
\text { Kompetensi }\end{array}$} & Kompetensi \\
\hline & & di sekolah/madrasah \\
\hline & & $\begin{array}{l}\text { 2.14 Mengelola sistem informasi sekolah/madrasah dalam } \\
\text { mendukung penyusunan program dan pengambilan } \\
\text { keputusan. }\end{array}$ \\
\hline & & $\begin{array}{l}\text { 2.15 Memanfaatkan kemajuan teknologi informasi bagi } \\
\text { peningkatan pembelajaran dan manajemen sekolah/madrasah }\end{array}$ \\
\hline & & $\begin{array}{l}\text { 2.16 Melakukan monitoring, evaluasi, dan pelaporan pelaksanaan } \\
\text { program kegiatan sekolah/madrasah dengan prosedur yang } \\
\text { tepat, serta merencanakan tindak lanjutnya. }\end{array}$ \\
\hline \multirow[t]{5}{*}{3.} & \multirow[t]{5}{*}{$\begin{array}{l}\text { Kewirausaha- } \\
\text { an }\end{array}$} & 3.1 $\begin{array}{l}\text { Menciptakan inovasi yang berguna bagi pengembangan } \\
\text { sekolah/madrasah. }\end{array}$ \\
\hline & & $\begin{array}{ll}3.2 & \text { Bekerja keras untuk mencapai keberhasilan sekolah/madrasah } \\
\text { sebagai organisasi yang efektif }\end{array}$ \\
\hline & & $\begin{array}{l}\text { Memiliki motivasi yang kuat untuk sukses dalam malaksanakan } \\
\text { tugas pokok dan fungsinya sebagai pemimpin } \\
\text { sekolah/madrasah }\end{array}$ \\
\hline & & $\begin{array}{l}\text { 3.4 Pantang menyerah dan selalu mencari solusi terbaik dalam } \\
\text { menghadapi kendala yang dihadapi sekolah/madrasah }\end{array}$ \\
\hline & & $\begin{array}{l}\text { Memiliki naluri kewirausahaan dalam mengelola kegiatan } \\
\text { produksi/jasa sekolah/madrasah sebagai sumber belajar } \\
\text { peserta didik. }\end{array}$ \\
\hline \multirow[t]{3}{*}{4.} & \multirow[t]{3}{*}{ Supervisi } & $\begin{array}{l}\text { 4.1 Merencanakan program supervisi akademik dalam rangka } \\
\text { peningkatan profesionalisme guru }\end{array}$ \\
\hline & & $\begin{array}{l}\text { Melaksanakan supervisi akademik terhadap guru dengan } \\
\text { menggunakan pendekatan dan teknik supervisi yang tepat. }\end{array}$ \\
\hline & & $\begin{array}{l}\text { 4.3 Menindaklanjuti hasil supervisi akademik terhadap guru dalam } \\
\text { rangka peningkatan profesionalisme guru }\end{array}$ \\
\hline \multirow[t]{3}{*}{5.} & \multirow[t]{3}{*}{ Sosial } & $\begin{array}{ll}\text { 5.1 } & \begin{array}{l}\text { Bekerja sama dengan pihak lain untuk kepentingan } \\
\text { sekolah/madrasah }\end{array}\end{array}$ \\
\hline & & 5.2 Berpartisipasi dalam kegiatan sosial kemasyarakatan. \\
\hline & & 5.3 Memiliki kepekaan sosial terhadap orang atau kelompok lain. \\
\hline
\end{tabular}

Kompetensi yang dimaksud dalam tulisan ini adalah kompetensi manajerial. Jika merujuk kepada tabel di atas, setidaknya ada 16 kompetensi dasar yang berhubungan dengan kompetensi manajerial seorang kepala SMA yang berbasis Islam. Kompetensi manajerial menurut Wahyudi (2012: 68) adalah kemampuan seseorang dalam mengelola sumberdaya organisasi berdasarkan kompetensi yang ditetapkan dalam rangka mencapai tujuan yang telah ditetapkan. Robert Katz (dalam Wahyudi, 2012: 64) mengemukakan ada tiga macam keterampilan manajerial yang diperlukan oleh seorang kepala sekolah dalam mengelola sumber daya organisasi sekolah yakni keterampilan konseptual (conceptual skills), keterampilan hubungan manusia (buman skills), dan keterampilan teknis (technical skills). Jenis keterampilan tersebut dibedakan berdasarkan tingkatan manajer dalam organisasi. Pada dasarnya, keterampilan hubungan 
manusia (buman skills) diperlukan pada semua tingkatan manajer karena manusia sebagai aset organsiasi sangat menentukan keberlangsungan organisasi. Keterampilan teknik sangat dibutuhkan pada tingkatan manajer rendah. Pada tingkat manajer puncak, keterampilan konseptual lebih dibutuhkan.

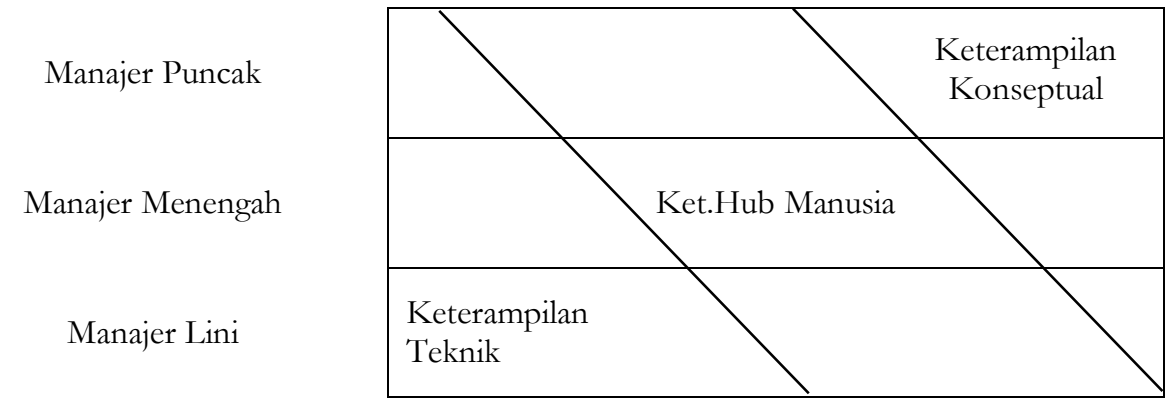

Keterampilan konseptual adalah kemampuan yang harus dimiliki oleh kepala sekolah untuk melihat sekolah secara keseluruhan, seperti dalam merencanakan perubahan, merancang tujuan sekolah, membuat penilaian secara tepat tentang keefektifan kegiatan sekolah dan mengoordinasikan program secara harmonis (Dubin, 1991 dalam Wahyudi, 2012: 33). Keterampilan konseptual diperlukan dalam perencanaan, pengorganisasian, menentukan kebijaksanaan, pemecahan masalah dan pengambilan keputusan dalam pengembangan program sekolah. Keterampilan yang berkenaan dengan hubungan manusia dalam organisasi pendidikan adalah kemampuan kepala sekolah untuk mendirikan sistem komunikasi dua arah yang terbuka dengan personil sekolah dan anggota masyarakat lain untuk menciptakan suasana kepercayaan terhadap sekolah dan meningkatkan unjuk kerja guru (Sutisna, 1993 dalam Wahyudi, 2012: 33). Keterampilan teknis kepala sekolah adalah kemampuan kepala sekolah dalam menanggapi dan memahami secara cakap penggunaan metode-metode termasuk aspek yang bukan pengajaran seperti pengetahuan keuangan, pelaporan, penjadwalan dan pemeliharaan. Wahjosumidjo (2011: 101) berpendapat bahwa agar kepala sekolah secara efektif dapat melaksanakan fungsinya sebagai manajer, kepala sekolah harus memahami dan mampu mewujudkan ke dalam tindakan atau perilaku nilai-nilai yang terkandung di dalam ketiga keterampilan yakni:

1. Technical Skills

a. Menguasai pengetahuan tentang metode, proses, prosedur, dan teknik untuk melaksanakan kegiatan khusus.

b. Kemampuan untuk memanfaatkan serta mendayagunakan sarana, peralatan yang diperlukan dalam mendukung kegiatan yang bersifat khusus tersebut.

2. Human Skills

a. Kemampuan untuk memahami perilaku manusia dan proses kerja sama. 
b. Kemampuan untuk memahami isi hati, sikap dan motif orang lain, mengapa mereka berkata dan berperilaku.

c. Kemampuan untuk berkomunikasi secara jelas dan efektif.

d. Kemampuan menciptakaan kerja sama yang efektif, kooperatif, praktis dan diplomatis.

e. Mampu berperilaku yang dapat diterima.

3. Conceptual Skills
a. Kemampuan analisis.
b. Kemampuan berpikir rasional.
c. Ahli atau cakap dalam berbagai macam konsepsi.
d. Mampu menganalisis berbagai kejadian, serta mampu memahami berbagai kecenderungan.
e. Mampu mengantisipasikan perintah.
f. Mampu mengenali macam-macam kesempatan dan problem- problem sosial.

Wahyudi (2012: 62) menunjukkan ada tujuh kompetensi dasar yang harus dimiliki seorang kepala sekolah dalam menjalankan tugasnya, yakni; 1) kompetensi merumuskan visi, 2) kompetensi merencanakan program, 3) kompetensi membangun komunikasi, 4) kompetensi hubungan masyarakat dan kerjasama, 5) kompetensi mengelola sumber daya, 6) kompetensi pengambilan keputusan, dan 7) kompetensi mengelola konflik.

Wiles dalam Wahyudi (2012: 33-34) mengemukakan bahwa kompetensi keterampilan yang diperlukan kepala sekolah meliputi; skill in leadership, skill in buman relationship, skill in group process, skill in personal administration, dan skill in evaluation. Keterampilan dalam kepemimpinan (skill in leadership) yaitu kepala sekolah dapat mempengaruhi dan mengarahkan bahwa (guru-guru) untuk mencapai tujuan sekolah melalui kegiatan-kegiatan; (a) meningkatkan prestasi anggota dalam menyusun program sekolah, (b) menciptakan iklim kerja yang kondusif, (c) mendelegasikan sebagian tanggung jawab dan mengikutsertakan guru-guru untuk membuat keputusan, (d) mendorong kreativitas anggota dan memberikan kesempatan guru untuk tampil.

Keterampilan hubungan insani (skill in buman relationship) yaitu kepala sekolah mampu menjalin kerjasama dengan seluruh personel sekolah; bersikap melayani bawahan, menghargai perbedaan pendapat, dan bersikap ramah. Keterampilan dalam proses kelompok (skill in group process) artinya kepala sekolah terlibat dalam proses kerjasama kelompok, dengan demikian kepala sekolah mengetahui kelebihan dan kekurangan bawahan dalam bekerja. Dalam proses kerja kelompok dapat menumbuhkan sikap saling percaya dan saling membantu antara pemimpin dan anggota. Kepala sekolah bersikap arif dan bijaksana dalam menghadapi pertentangan yang muncul dalam kelompok. Selama berlangsungnya proses kelompok, kepala sekolah memimpin diskusi, rapat dan pertemuan-pertemuan dengan masyarakat. 
Keterampilan dalam mengelola personel (skill in personal administration) yaitu keterampilan kepala sekolah dalam menempatkan personil pada suatu pekerjaan (job) sesuai dengan kemampuan yang dimiliki. Karena itu, kepala sekolah harus selalu mengikuti perkembangan ilmu pengetahuan dan lingkungan terutama perubahan situasi pekerjaan. Keterampilan dalam penilaian (skill in evaluation) yaitu keterampilan kepala sekolah untuk mengetahui pencapaian suatu pelaksanaan pekerjaan melalui langkah-langkah; (1) menetapkan standar pekerjaan, (2) membandingkan hasil kerja aktual dengan standar yang ditetapkan, (3) mengadakan koreksi bila diperlukan.

Dengan bekal keterampilan yang dimilikinya, kepala sekolah diharapkan dapat menjalankan fungsi kepemimpinannya dengan baik sehingga menjadi sosok yang memberi inspirasi bagi para personil sekolah untuk mengoptimalkan kinerjanya dalam mendukung pencapaian visi dan misi sekolah. Kepemimpinan yang mampu melahirkan budaya sekolah yang kondusif bagi para pendidik dan tenaga kependidikan untuk berkarya dengan baik serta bagi peserta didik untuk belajar dengan baik menjadi tantangan kepala sekolah. Wahjosumidjo (2011: 106-119) mengungkapkan bahwa kepala sekolah sebagai pemimpin seharusnya dalam praktik sehari-hari selalu berusaha memperhatikan delapan fungsi kepemimpinan di dalam kehidupan sekolah.

1. Dalam kehidupan sehari-hari kepala sekolah akan dihadapkan kepada sikap para guru, staf, dan para siswa yang mempunyai latar belakang kehidupan, kepentingan serta tingkat sosial budaya yang berbeda sehingga tidak mustahil terjadi konflik antar individu bahkan antar kelompok.

2. Sugesti atau saran sangat diperlukan oleh para bawahan dalam melaksanakan tugas. Para guru, staf dan siswa suatu sekolah hendaknya selalu mendapatkan saran, anjuran dari kepala sekolah sehingga dengan saran tersebut selalu dapat memelihara bahkan meningkatkan semangat, rela berkorban, rasa kebersamaan dalam melaksanakan tugas masing-masing (suggesting).

3. Dalam mencapai tujuan setiap organisasi memerlukan dukungan, dana, saran dan sebagainya. Demikian pula sekolah sebagai suatu organisasi dalam rangka mencapai tujuan yang telah digariskan memerlukan berbagai dukungan.

4. Kepala sekolah berperan sebagai katalisator, dalam arti mampu menimbulkan dan menggerakkan semangat para guru, staf dan siswa dalam mencapai tujuan yang telah ditetapkan.

5. Rasa aman merupakan salah satu kebutuhan setiap orang baik secara individu maupun kelompok. Oleh sebab itu, seorang kepala sekolah sebagai pemimpin harus dapat menciptakan rasa aman di dalam lingkungan sekolah, sehingga para guru, staf dan siswa dalam melaksanakan tugasnya merasa aman, bebas dari segala perasaan 
gelisah, kekhawatiran, serta memperoleh jaminan keamanan dari kepala sekolah (providing security).

6. Seorang kepala sekolah selaku pemimpin akan menjadi pusat perhatian, artinya semua pandangan akan diarahkan ke kepala sekolah sebagai orang yang mewakili kehidupan sekolah di mana, dan dalam kesempatan apa pun.

7. Kepala sekolah pada hakikatnya adalah sumber semangat bagi para guru, staf dan siswa. Oleh sebab itu, kepala sekolah harus selalu membengkitkan semangat, percaya diri terhadap para guru, staf dan siswa, sehingga mereka menerima dan memahami tujuan sekolah secara antusias, bekerja secara tanggung jawab ke arah tercapainya tujuan sekolah (inspiring).

8. Setiap orang dalam kehidupan organisasi baik secara pribadi maupun kelompok, apabila kebutuhannya diperhatikan dan dipenuhi, maka dia akan merasa sangat dihargai. Untuk itu, kepala sekolah harus dapat menghargai apa pun yang dihasilkan oleh para guru, staf dan siswa yang menjadi tanggung jawabnya.

Sistem kompensasi sama dengan sistem kesejahteraan yang diterapkan suatu lembaga terhadap personalia yang terlibat dalam proses manajemen, dari mulai top pimpinan sampai staf yang paling rendah. Sistem kompensasi kepala sekolah dimaknai sama dengan kesejahteraan yang diterima kepala sekolah sebagai imbalan atas proses kepemimpinan yang dilaksanakannya. Kesejahteraan merupakan imbalan (langsung maupun tidak langsung) yang diterima oleh setiap karyawan atau pegawai setelah mereka berkarya bagi suatu organisasi/lembaga melalui keterampilan, pengetahuan dan waktu mereka. Simamora (1995: 412) menjelaskan, "kesejahteraan adalah bentuk kembalian (return), financial, jasa-jasa berwujud dan tunjangan-tunjangan yang diperoleh karyawan sebagai bagian dari sebuah hubungan kepegawaian." Berarti kesejahteraan itu dapat diidentikan dengan imbalan atau jasa yang diberikan perusahaan kepada karyawan yang dinilai dengan uang. Dengan demikian kesejahteraan karyawan merupakan segala macam bentuk pembayaran atau imbalan yang diberikan kepada karyawan dan timbul dari hasil kerja karyawan itu.

\section{Karakteristik Kepala SMA Berbasis Islam Di Jawa Barat}

Jenis kelamin kepala sekolah pada sekolah berbasis Islam yang diteliti, sebagian besar berjenis kelamin laki-laki (84,90\%) sedangkan sisanya yang berjenis kelamin perempuan hanya $15,10 \%$. Data tersebut menunjukkan, bahwa dalam pemahaman umum hal tersebut sudah sesuai dengan kaidah Islam (Q.S. An-Nisa [4]: 34) bahwa laki-laki diciptakan Allah SWT sebagai pemimpin. Kepala sekolah SMA pada sekolah yang berbasis Islam di Jawa Barat ini, sebagian besar berpendidikan S1 yakni sebanyak 49,06\% dan yang berlatar belakang pendidikan S2 sebanyak 18,87\% sedangkan sisanya 32,08\% tidak teridentifikasi (tidak menyebutkan). Hal ini sesuai dengan Peraturan Menteri 
Pendidikan Nasional Nomor 13 tahun 2007 tentang standar sekolah dan madrasah, bahwa syarat-syarat menjadi kepala sekolah harus memiliki kualifikasi umum dan khusus. Kualifikasi umum yang dimaksud antara lain memiliki kualifikasi akademik sarjana (S1) atau diploma empat (D-IV). Dari hasil penelitian, teridentifikasi bahwa berdasarkan latar belakang pendidikannya, ternyata kepala sekolah yang latar belakang sarjana kependidikan sebanyak $38,89 \%$ sedangkan yang berlatar belakang sarjana non kependidikan sebanyak $30,56 \%$ dan sisanya sebanyak 30,56\% tidak diketahui. Kepala sekolah yang berlatarbelakang pendidikan keagamaan baik S1 maupun S2 sebesar 25\%, sedangkan yang tidak secara khusus berpendidikan keagamaan, baik S1 maupun S2 sebanyak 47,22\%, dan sisanya 27,78\% tidak diketahui. Usia kepala sekolah di SMA berbasis Islam di Jawa Barat umumnya berusia dibawah 40 tahun yakni sebanyak 30,19\% disusul berusia 46-50 tahun sebanyak 22,64\%, usia 40-45 tahun dan 51-55 tahun sebanyak 16,98\%, usia 56-60 tahun $11,32 \%$ dan sisanya $1,89 \%$. Artinya hanya ada seorang kepala sekolah di SMA yang berbasis Islam di Provinsi Jawa Barat yang berusia di atas 65 tahun yakni berusia 69 tahun. Bila mengacu kepada Peraturan Menteri Pendidikan Nasional Nomor 13 tahun 2007 seharusnya pada waktu diangkat sebagai kepala sekolah ia berusia setingitingginya 56 tahun. Oleh karena itu, berdasarkan data tersebut, kemungkinan besar ia sudah berkali-kali (setidaknya dua kali) menjadi kepala sekolah.

Hasil penilain guru dan karyawan terhadap kepala sekolah pada SMA yang berbasis Islam di Jawa Barat menunjukkan bahwa;

1. Perilaku kepemimpinan berada pada posisi 4.17, masuk pada kategori sangat baik. Harapan guru terhadap perilaku kepemimpinan yang ada agar menjadi lebih baik lagi dibanding saat ini yaitu sebesar 4.6. berarti terdapat gap senilai 0.43 .

2. Motivasi kepemimpinan kepala sekolah berada pada posisi 4.01, masuk pada kategori sangat baik. Guru dan karyawan berharap motivasi kepala sekolah masih bisa ditingkatkan. Hal ini terlihat dari nilai harapan guru dan karyawan sebesar 4.87, sehingga ada gap sebesar 0.86 .

3. Kemampuan manajerial kepala sekolah berada pada posisi 4.34, masuk pada kategori sangat baik. Guru dan karyawan masih berharap adanya peningkatan kemampuan manajerial kepala sekolah. Hal ini terlihat dari hasil penilaian sebesar 4.87 dengan demikian masih ada gap senilai 0.57 .

4. Sistem kompensasi berada pada posisi 3.68, berarti berada dalam kategori baik. Guru dan karyawan masih sangat berharap bahwa kompensasi yang dapat meningkatkan kinerja kepala sekolah. Hal terlihat dari penilain mereka sebesar 4.76 atau meningkat sebesar 1.08.

5. Kinerja kepala sekolah berada pada posisi 4.08, berarti dalam kategori baik. Rata-rata guru/karyawan berharap kinerja kepala sekolah masih bisa ditingkatkan memperoleh skor 4.86 atau masih ada gap senilai 0.9. 
Tingkat kesesuaian antara kenyataan dengan harapan atas kinerja kepala sekolah pada SMA berbasis Islam di Jawa Barat dianalisis berdasarkan diagram matriks competitive performance dengan benefit importance, yakni dengan melihat indikator sejumlah indikator yang termasuk dalam kuadran A, B, C dan D untuk kinerja kepala sekolah. Dari 27 pertanyaan mengenai kinerja kepala sekolah kemudian dijabarkan/ditempatkan dalam tabel berikut;

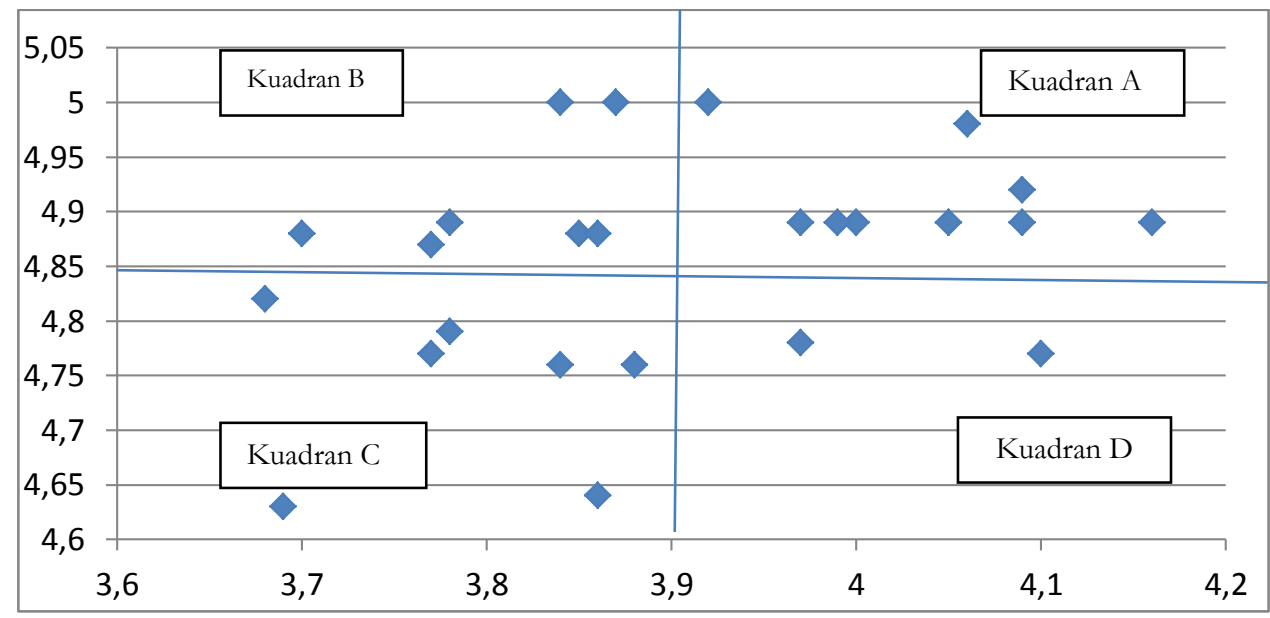

Ada sepuluh faktor yang terdapat pada kuadran A yaitu indikator yang menunjukkan unsur yang telah berhasil dilaksanakan dan untuk itu wajib dipertahankan, dianggap sangat penting dan sangat memuaskan oleh guru dan karyawan. Ada sembilan indikator kinerja yang ada pada kuadran B yaitu indikator yang menunjukkan unsur-unsur yang dianggap guru/karyawan sangat penting tapi oleh kepala sekolah kurang diperhatikan. Ada enam faktor yang ada pada kuadran $C$, yaitu indikator yang menunjukkan unsur yang kurang penting pengaruhnya bagi guru dan karyawan dan kurang memuaskan. Ada dua faktor yang ada pada kuadran D, yaitu indikator yang menunjukkan unsur yang menurut guru dan karyawan tidak penting, tetapi dilaksanakan oleh kepala sekolah bahkan cenderung berlebihan.

Apabila dibandingkan dengan potensi Kepala SMA berbasis Islam yang menjadi objek penelitian, maka kinerja Kepala SMA bisa ditingkatkan, karena dari sisi usia, kepala sekolah yang ada relatif masih muda (30,19\%) yakni berusia dibawah 40 tahun dan lebih dari 60\% berpendidikan S1 atau S2. Oleh karenanya yang diperlukan adalah strategi peningkatan kinerja kepala sekolah. Penentuan strategi yang tepat dilakukan melihat indikator yang termasuk dalam kuadran A, B, C dan D. Indikator yang masuk dalam kuadran B merupakan prioritas utama. Indikator yang termasuk dalam kuadran A merupakan upaya mempertahankan prestasi, yaitu tersedianya : (1) rencana strategis sekolah, (2) rencana operasional sekolah, (3) RAPBS, (4) analisa kontekstual, (5) dokumen KTSP, (6) struktur 
organisasi dan tata kerja manajemen sekolah, (7) pendik dan tendik dalam proses perencanaan manajemen sekolah, dan (8) memiliki inisiatif yang tinggi dalam mengembangkan program strategis.

Indikator yang termasuk dalam kuadran $C$ (prioritas rendah) adalah: (1) selalu menggerakkan personel sekolah, (2) memiliki kemampuan teknis, (3) memiliki disiplin yang tinggi, (4) menindak-lanjuti hasil evaluasi/pemanfaatan evaluasi, (5) melibatkan pendidik dan karyawan dalam proses evaluasi, dan (6) melakukan tindakan penelitian tindakan sekolah. Indikator kuadran $\mathrm{C}$ juga dapat dianggap sebagai indikator pendukung untuk menambah daya tarik, meskipun guru dan karyawan beranggapan indikator ini tidak penting. Indikator yang termasuk dalam kuadran D (berlebihan) adalah: Inisiatif yang tinggi dalam segala bidang dan melayani keinginan guru, karyawan dan orang yang berkepentingan dengan sekolah tersebut. Dengan mengategorikan instrumen kepemimpinan dalam pengelompokan sifat utama Rasulullah yakni shiddîq, amânah, fathânah dan tabligh terlihat bahwa pada kuadran B yakni terdiri atas shiddîq berjumlah 3, amânah 1, fathânah 5 dan tablìgh 2.

\begin{tabular}{|c|l|l|c|}
\hline \multirow{2}{*}{ NO } & \multicolumn{1}{|c|}{ SIFAT RASULULLAH } & \multicolumn{1}{|c|}{ KUADRAN B } & JUMLAH \\
\hline 1 & SHIDDIQ & 2.4 .16 & 3 \\
\hline 2 & AMÂNAH & 10 & 1 \\
\hline 3 & FATHÂNAH & $6,8,11,12,15$ & 5 \\
\hline 4 & TABLÎH & 7,17 & 2 \\
\hline
\end{tabular}

Faktor-Faktor yang Mempengaruhi Kinerja Kepala SMA Berbasis Islam di Jawa Barat

Hasil perhitungan analisis jalur (path analysis) perilaku kepemimpinan (X1), motivasi kerja (X2), kemampuan manajerial (X3) dan sistem kompensasi (X4) terhadap kinerja kepala sekolah (Y) menunjukkan bahwa faktor-faktor determinan yang mempengaruhi kinerja kepala sekolah secara korelasional diperoleh angka tertinggi adalah kepemimpinan (X1) terhadap kinerja kepala sekolah (Y), yaitu sebesar 0,716 dan terendah terdapat pada sistem kompensasi (X4) terhadap kinerja kepala sekolah (Y) yaitu sebesar 0,539. Secara matriks korelasi antar variabvel eksogenus (variabel bebas) diperoleh korelasi tertinggi berada di antara variabel kepemimpinan (X1) dengan motivasi kerja (X2). Sedangkan korelasi terendah terdapat pada hubungan antara kemampuan manajerial (X3) dan sistem kompensasi (X4) yaitu sebesar 0,380.

Didasarkan pada kerangka teori ternyata ada pengaruh faktor-faktor determinan yang mempengaruhi kinerja kepala sekolah. Hipotesis kemudian diuji dengan cara menguji semua koefisien jalur PYXi secara keseluruhan melalui statistik uji $\mathrm{F}$ dan diperoleh $\mathrm{F}=75,754$. F tabel dengan $\mathrm{db}_{1}=\mathrm{k}=4$; $\mathrm{db}_{2}=\mathrm{n}-\mathrm{k}-1$ = 176-3-1 dan taraf kesalahan $\alpha=5 \%$ adalah 2,425. Uji koefisien jalur secara keseluruhan dapat dilihat dari $\mathrm{F}$ hitung 75,754 yang ternyata lebih besar dari F tabel 2,425, maka $\mathrm{H}_{0}$ ditolak. Hal ini berarti koefisien jalur benar-benar 
menunjukkan pengaruh sesuai diagram konseptual yang dihipotesiskan. Besar pengaruh perilaku kepemimpinan (X1), motivasi kerja (X2), kemampuan manajerial (X3), dan sistem kompensasi (X4) terhadap kinerja kepala sekolah (Y) pada sekolah berbasis Islam di Jawa Barat, diperoleh $\mathrm{R}^{2}=0,639$. Ini dilakukan dengan menghitung koefisien determinasi seluruh variabel $\mathrm{X}$ terhadap $\mathrm{Y}$ :

\begin{tabular}{|c|c|c|c|c|c|c|c|c|c|c|c|c|c|c|}
\hline \multirow{3}{*}{$\begin{array}{l}\text { Var } \\
\text { X1 }\end{array}$} & \multirow{2}{*}{\multicolumn{2}{|c|}{$\begin{array}{l}\text { Pengaruh } \\
\text { Langsung }\end{array}$}} & \multicolumn{10}{|c|}{ Pengaruh Tidak Langsung, melalui } & \multirow{2}{*}{\multicolumn{2}{|c|}{ Total }} \\
\hline & & & \multicolumn{2}{|l|}{$\mathrm{X} 1$} & \multicolumn{2}{|c|}{$\mathrm{X} 2$} & \multicolumn{2}{|c|}{ X3 } & \multicolumn{2}{|c|}{$\mathrm{X} 4$} & \multicolumn{2}{|c|}{ Sub Total } & & \\
\hline & $12,81 \%$ & + & - & & $2,79 \%$ & + & $7,08 \%$ & + & $2,95 \%$ & + & $12,82 \%$ & + & $25,6 \%$ & + \\
\hline $\mathrm{X} 2$ & $1,59 \%$ & + & $2,79 \%$ & + & - & & $2,39 \%$ & + & $0,94 \%$ & + & $6,13 \%$ & + & $7,7 \%$ & + \\
\hline $\mathrm{X} 3$ & $11,25 \%$ & + & $7,08 \%$ & + & $2,39 \%$ & + & - & & $1,89 \%$ & + & $11,36 \%$ & + & $22,6 \%$ & + \\
\hline $\mathrm{X} 4$ & $2,19 \%$ & + & $2,95 \%$ & & $0,94 \%$ & & $1,89 \%$ & & - & & $5,78 \%$ & + & $8,0 \%$ & + \\
\hline \multicolumn{13}{|c|}{ Pengaruh Variabel X1, X2, X3, X4 } & $63,9 \%$ & \\
\hline \multicolumn{13}{|c|}{ Pengaruh Variabel luar } & $36,1 \%$ & \\
\hline \multicolumn{13}{|c|}{ Total } & $100,0 \%$ & \\
\hline
\end{tabular}

Besarnya pengaruh masing-masing faktor adalah: (1) kepemimpinan berpengaruh secara langsung dan tidak langsung terhadap kinerja kepala sekolah berbasis Islam di Jawa Barat sebesar 25,6\%, (2) Motivasi kerja berpengaruh secara langsung dan tidak langsung terhadap kinerja kepala sekolah berbasis Islam di Jawa Barat sebesar 7,7\%, (3) Kemampuan manajerial berpengaruh secara langsung dan tidak langsung terhadap kinerja kepala sekolah berbasis Islam di Jawa Barat sebesar 22,6\%, dan (4) Sistem kompensasi berpengaruh secara langsung dan tidak langsung terhadap kinerja kepala sekolah berbasis Islam di Jawa Barat sebesar 8,0\%. Hasil ini menunjukkan bahwa faktor-faktor determinan yang memiliki pengaruh paling besar dalam mempengaruhi kinerja kepala sekolah adalah kepemimpinan dan yang kedua kemampuan manajerial. Sedangkan faktor motivasi kerja dan sistem kompensasi memiliki pengaruh yang kecil, namun cukup signifikan.

\section{SIMPULAN}

Perilaku kepemimpinan, motivasi, kemampuan manajerial dan sistem kompensasi merupakan empat faktor yang secara langsung maupun tidak mempengaruhi kinerja kepala SMA berbasis Islam di Jawa Barat. Besarnya pengaruh masing-masing faktor yaitu; 1) kepemimpinan sebesar 25,6\%; 2) motivasi kerja sebesar 7,7\%; 3) kemampuan manajerial sebesar 22,6\%; dan 4) sistem kompensasi sebesar 8,0\%. Besarnya pengaruh langsung dan tidak langsung untuk perilaku kepemimpinan dan kemampuan manajerial hampir sama yaitu (kepemimpinan: langsung 12,81\%, tidak langsung 12,79\%, manajerial: langsung 11,25\%, tidak langsung 11,35\%) sedangkan untuk motivasi dan sistem kompensasi, pengaruh tidak langsung lebih besar dari pengaruh langsung (motivasi: langsung 1,59\%, tidak langsung 6,11\%; kompensasi: langsung 2,19\%, tidak langsung 5,89). Berarti, ke empat faktor tersebut saling mempengaruhi. 
Urutan besarnya penilaian terhadap faktor-faktor di atas yaitu; 1) Faktor kepemimpinan, menunjukkan rata-rata nilai 4,17, kategori sangat baik karena tingkat kesesuaian $90,35 \%$; 2) Motivasi dengan rata-rata nilai 4.01 atau tingkat kesesuaian 83.34\%; 3) Kemampuan manajerial yang dinilai oleh guru dan karyawan juga berada dalam kategori sangat baik dengan rata-rata 4.34 dan tingkat kesesuaiannya mencapai $92.18 \%$. Sedangkan sistem kompensasi yang dinilai oleh guru dan karyawan berada dalam kategori baik (rata rata 3.48 dengan tingkat kesesuaian sebesar 77.31\%). Dilihat dari usia dan pendidikan, maka kepala SMA berbasis Islam di Jawa Barat merupakan potensi yang harus dikembangkan karena rata-rata kepala sekolah SMA yang berbasis Islam di wilayah Provinsi Jawa Barat berusia relatif muda dan merupakan jumlah mayoritas yakni 30.19\%. Umumnya mereka berusia di bawah 40 tahun dan hampir 50\% berada di bawah usia 45 tahun. Mereka pun umumnya (lebih dari $67 \%$ ) berpendidikan S1 dan atau S2. Untuk meningkatkan kinerja kepala SMA berbasis Islam di Jawa Barat dilakukan dengan cara memperbaiki indikator yang ada pada kuadran A yakni indikator yang menunjukkan unsur-unsur yang dianggap sangat penting dalam kinerja kepala sekolah namun diterima oleh guru dan karyawan belum sesuai dengan harapan, mengecewakan atau tidak memuaskan. Indikator yang termasuk ke dalam kuadran ini yaitu kepala sekolah; mengomunikasikan visi dan misi sekolah kepada guru dan karyawan; melakukan supervisi, mampu bekerja sama; hasil kerjanya berkualitas; bersemangat; memiliki daya tahan/kehandalan; cepat dalam menyelesaikan masalah; dan melakukan evaluasi ketercapaian program. Mempertahankan indikator yang berada pada kuadran B yakni indikator yang menunjukkan unsur-unsur yang telah berhasil dilaksanakan, dianggap sangat penting dan memuaskan. Indikator tersebut adalah tersedianya rencana strategis sekolah, rencana operasional, RAPBS, analisa kontekstual, dokumen KTSP, struktur organisasi dan tata kerja manajemen sekolah, pendidik dan tenaga pendidik dalam proses perencanaan manajemen sekolah serta memiliki inisiatif yang tinggi dalam mengembangkan program strategis. Indikator yang termasuk dalam kuadran C (prioritas rendah) adalah unsur-unsur yang kurang penting pengaruhnya bagi guru dan karyawan sehingga diterima biasa-biasa saja. Indikator di kuadran ini menyangkut efesiensi kerja, menggerakkan personel sekolah, memiliki kemampuan teknis, memiliki disiplin yang tinggi, menindak lanjuti hasil evaluasi/pemanfaatan evaluasi, melibatkan pendidik dan karyawan dalam proses evaluasi dan melakukan tindakan penelitian tindakan sekolah. Indikator yang termasuk dalam kuadran D (berlebihan) adalah menunjukkan unsur-unsur yang mempengaruhi, akan tetapi dilaksanakan oleh kepala sekolah secara berlebihan. Kepala sekolah telah menunaikannya dengan dengan baik karena itu harus dipertahankan. Indikator ini menjadi daya tarik untuk meningkatkan kepuasan guru dan karyawan serta menjadi langkah awal kepala sekolah untuk melaksanakan indikator yang ada pada kuadran A. Indikator yang termasuk dalam kuadran D adalah inisiatif yang tinggi dalam segala bidang, melayani keinginan guru, karyawan dan siapa pun 
yang berhubungan dengan pendidikan. Dari empat karakteristik kepemimpinan Rasulullah SAW, sifat fathanah adalah yang paling banyak termasuk dalam kuadran B sehingga perlu mendapatkan perhatian dari kepala SMA berbasis Islam di Jawa Barat.

\section{DAFTAR PUSTAKA}

Al Banjari, Rachmat, Ramadhana. 2008. Prophetic Leadership. Yogyakarta: Diva Press.

Al Maragi. 1994. Tafsir Al Maragi. Beirut.

Antonio, Syafii, Muhammad. 2008. Muhammad SAW, The Super Leader super manager. Jakarta: Tazkia Multimedia.

Cascio, Wayne, and Aguinnis, Herman. 2005. Applied Psychology in Human Resource Management, Sixth Edition. New Jersey: Pearson Prentice Hall.

Danim, Sudarwan. 2000. Inovasi Pendidikan. Bandung: Pustaka Setia.

Daryanto. 2011. Kepala Sekolah sebagai Pemimpin Pembelajaran. Yogyakarta: Gava Media.

Fahmi, Irman. 2011. Manajemen Kinerja: Teori dan Aplikasi. Bandung: Alfabeta.

http://www.ban-sm.or.id/provinsi/jawa-barat/akreditasi/view/163947 diunduh pada tanggal 13 Februari 2013.

Indrafachrudi, Soekarto. 2006. Bagaimana Memimpin Sekolah yang Efektif. Bogor: Ghalia Indonesia.

Katsir, Ibnu. 1972. Tafsir Ibnu Katsir. Bairut.

Mathis, Robert, L and Jackson, John, H. 2010. Human Resource Management. Thirteen Edition. USA: South-Western Cengage Learning. Electronic version.

Mulyasa. 2011. Manajemen dan Kepemimpinan Kepala Sekolah.Jakarta: Bumi Aksara.

Peraturan Menteri Pendidikan Nasional Republik Indonesia Nomor 13 Tahun 2007 tentang Standar Kepala Sekolah/Madrasah.

Wahdjosumidjo. 2011. Kepemimpinan Kepala Sekolah: Tinjanan Teoretik dan Permasalahannya. Jakarta: Raja Grafindo Persada.

Wahyudi. 2012. Kepemimpinan Kepala Sekolah dalam Organisasi Pembelajar (Learning Organization). Bandung: Alfabeta.

Winardi. 2011. Motivasi dan Pemotivasian. Jakarta: Rajawali Pers.

Simamora, Henry. 1995. Manajemen Sumberdaya Manusia. Yogyakarta: STIE YPKN. 